
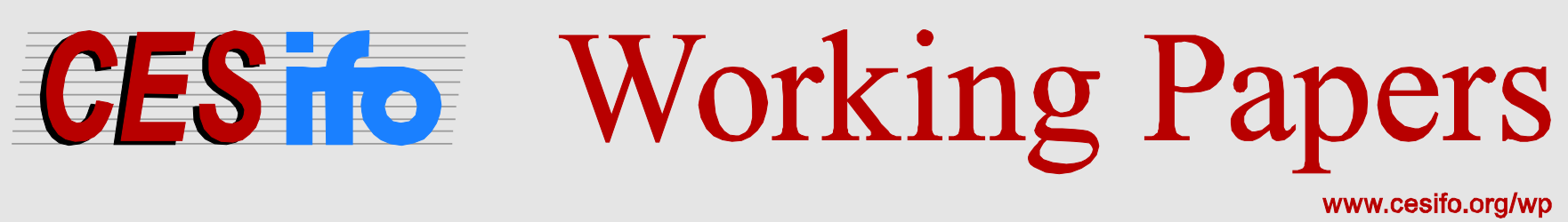

\title{
The Structure of Cigarette Excises in the EU: From Myths to Reality
}

\author{
Marko Primorac \\ Silvija Vlah Jerić
}

CESIFO WORKING PAPER NO. 6386

CATEGORY 1: PUBLIC FinANCE

MARCH 2017

An electronic version of the paper may be downloaded

- from the SSRN website:

- from the RePEc website:

- from the CESifo website:

www.SSRN.com

www.RePEc.org

www.CESifo-group.org/wp 


\title{
The Structure of Cigarette Excises in the EU: From Myths to Reality
}

\begin{abstract}
Although it may at first seem unimportant, the structure of excise taxes on cigarettes greatly affects the price of cigarettes, the structure of the consumption, but also the amount of the tax revenue. EU Directive 2011/64/EU prescribes the combination of the specific and the proportional (ad valorem) excise tax on cigarettes. However, Member States independently determine the shares of one or another component in the overall excise tax structure, whereby the EU directive only prescribes the upper and the lower limit. The purpose of this article is to challenge several myths related to the cigarette taxation in the EU. The first one is that an increase of the specific component of the cigarette excise negatively affects the consumption of cigarettes, whereas this does not hold for the proportional component. The second assumption empirically tested in the paper is that an increase of the specific excise increases the government revenue from cigarette excises, whereby this can not be confirmed for the proportional component. Lastly, since both previous hypotheses have been confirmed, we tried to delve into reasons why certain countries - despite obvious advantages of the specific in relation to proportional excise - still predominantly rely on the latter. To this end, we tested the assumption that countries with domestic production of tobacco increasingly use proportional excises to increase the price gap between domestic (usually cheaper) and more expensive (imported/international) brands. The results of the empirical analysis were consistent with this hypothesis and confirmed that domestic tobacco production is a significant determinant of the structure of cigarette excises.
\end{abstract}

JEL-Codes: H200, H300.

Keywords: cigarette excises, excise taxes, tax revenue, tax harmonization, EU.

\author{
Marko Primorac* \\ University of Zagreb \\ Faculty of Economics \& Business \\ Trg J.F. Kennedy 6 \\ Croatia-10000 Zagreb \\ mprimorac@efzg.hr
}

\author{
Silvija Vlah Jerić \\ University of Zagreb \\ Faculty of Economics \& Business \\ Trg J.F. Kennedy 6 \\ Croatia - 10000 Zagreb \\ svlah@efzg.hr
}

*corresponding author 


\section{Introduction}

Consumption of cigarettes has always been of interest for researchers in medical science. The reasons for that are obvious - it is estimated that tobacco use causes more than five million deaths per year worldwide (Mathers and Loncar, 2006). However, consequences of cigarette consumption have - over time - increasingly occupied also economists trying to evaluate economic costs of smoking but also various instruments for reducing the cigarette consumption. The cost of smoking in these analyses is usually decomposed into three categories: direct, indirect and induced costs. The first component relates to health care expenditure for treating smoking attributable diseases, the second one to productivity losses and the third one to premature mortality. Estimates of these costs are astonishing.

Ekpu and Brown (2015) claim that about $15 \%$ of health expenditure in high-income countries relates to negative effects of smoking. Moreover, in the US, smoking causes between $6 \%$ and $18 \%$ of health care expenditure across different states. ${ }^{1}$ According to their study, the economic burden of smoking in the US accounts for $1 \%$ of GDP, whereby productivity losses have been estimated at 151 billion USD per year. According to Lightwood et al. (2000) the total economic costs of smoking reaches $2.1 \%-3.4 \%$ of GDP in Australia, 1.3\%-2.2\% of GDP in Canada and 1.4\%-1.6\% of GDP in the United States (WHO, 2011).

The EU has been no exception confirming that the tobacco consumption represents a significant burden to the economy. According to GHK (2012), the total cost of smoking in the EU in 2009 came about $4.6 \%$ of the EU27' combined GDP ${ }^{2}$. Of that, $0.22 \%$ of GDP related to public healthcare expenditure (around $2.9 \%$ of total healthcare spending in the EU27), 0.06\% of GDP refers to smoking related productivity losses (absenteeism and economic inactivity due to incapacity) and $4.4 \%$ of GDP to premature mortality attributable to smoking.

Aiming at reduction of cigarette consumption, governments worldwide have implemented various policy measures with more or less effect. One of the most common measures from the economic arsenal is heavy taxation of cigarettes through excise taxes. Although they were primarily introduced to produce social (health) benefits, cigarette excises have a very pronounced fiscal (budgetary) effect. Both on the expenditure (decreasing the health care expenditures) and on the revenue side of the budget (collecting tax revenue). Total cigarette excise revenue in EU countries in 2015 amounted to 75 billion EUR or $0.5 \%$ of EU 28's GDP (according to Eurostat).

\footnotetext{
${ }^{1}$ Similar numbers have also been estimated for other high-income countries (see Warner and Hodgson et al., 1999 and World Bank, 1999).

${ }^{2}$ At that time, Croatia was still not the member of the EU.
} 
The excise tax on cigarettes consists of two components - specific and proportional (ad valorem). The specific excise tax is calculated in absolute terms and charged on a number of cigarettes, whereas the proportional excise tax is calculated in relative terms - usually a percentage of the retail price. ${ }^{3}$ The structure of the excise taxes significantly affects the consumption of cigarettes, their (relative) prices, budgetary revenue and the tobacco industry in general (Keen, 1998, Sunley et al., 2000; WHO, 2010). According to Keen (1998), Cournot (1960) was - writing in the 1830 s - the first to recognize that specific and proportional taxes had potentially different effects, whereas Wicksell (1959) and Suits and Musgrave (1955) further developed his pioneer work.

Over time, the literature has flourished with works tackling different aspects of specific vs. proportional taxation and examining from both the theoretical and the empirical perspective the influence of differing structures of taxation on prices (Barzel, 1976; Johnson, 1978; Stern, 1987; Delipalla, 1995), government revenue (e.g. Bohanon and van Cott, 1984; 1991; Kay and Keen, 1987; 1991; Myles, 1996; Keen, 1998; Delipalla and Keen, 2006), consumption (Delipalla and Keen, 1992; Chaloupka and Warner, 2000; Chaloupka et al., 2000; Delipalla and O'Donnell, 2001; Ross and Chaloupka, 2006), externalities (Pirttilä, 1997) and product quality and variety (Dixit and Stiglitz, 1977; Kay and Keen 1983; Cremer and Thisse, 1994; Anderson, de Palma and Kreider, 1997; Keen, 1998; Delipalla and Keen, 2006).

Since the 1970s, debates about harmonization of tobacco taxes in the European Union were mostly focused on the balance between specific and proportional components of cigarette excises (Keen, 1998). Despite various harmonization attempts - member states have not reached a consensus on the optimal structure of cigarette excises and proved reluctant to converge in this respect (see Delipalla and O'Donnell, 2001; Antonanzas and Rodriguez, 2007). The uneven structure of cigarette excises on the single European market should provide a solid base for testing different hypotheses related to the structure of cigarette excises. However, not much empirical work has been done. Keen (1998) mentions possible reason for this - pointing to serious drawbacks of underlying data. Although EU member states have largely differing shares of specific and proportional components, the structure of cigarette excises has been quite stable, hampering reliable analyses because of limited variation of variables over time.

However, the structure of the cigarette excises has changed over the last decade in literally all member states - at least marginally - giving us hope that the time has come when the new attempt could be worth it. Accordingly, this paper will tempt to make an empirical contribution to the existing stream of literature focusing on the influence of the structure of

\footnotetext{
${ }^{3}$ Retail price usually includes the excise tax, customs and value added tax.
} 
cigarette excises on the consumption and government revenue. The paper will analyze current structure and recent changes in the cigarette excises in EU countries. Moreover, the aim of the paper is to give an empirical justification of potential reasons why certain countries rely predominantly on one or another tax component.

Accordingly, the paper will test three hypotheses:

- H1: An increase in the specific component of the cigarette excises positively affects the excise tax revenue, whereas this can not be confirmed for the proportional component

- H2: An increase in the specific component of the cigarette excises negatively affects the consumption of cigarettes, whereas this can not be confirmed for the proportional component

- H3: Countries with domestic tobacco production increasingly rely on proportional component of the cigarette excise

After introduction, the second part provides a brief review of the literature challenging topics related to the structure of cigarette excises. The third part deals with the cigarette taxation in EU countries and comprehensively analyses the structure of the tax burden imposed on cigarettes. Recent trends in cigarette taxation are analyzed in the fourth part, whereas the fifth part is devoted to empirical justification of main hypotheses. The last - sixth - part is the conclusion.

\section{Brief overview of the theory of cigarette taxation}

The literature has in the last 50 years abounded with theoretical and empirical papers challenging various aspects of the structure of cigarette excises and examining implication of various shares of specific and proportional tax in the total tax burden. Influence of the excise structure on prices has been researched already in 1970s. It is clear that an increase in proportional excise increases the absolute price difference between lower and higher priced cigarettes, incentivizing consumers to substitute the consumption of expensive cigarettes with cheaper. Although it is believed that the demand for cigarettes is inelastic to price, Delipalla and Keen (1992) and Delipalla and O’Donnell (2001) claim that specific excises increase prices relatively more than proportional, having a positive impact on the reduction of consumption. This is also confirmed by Barzel (1976), Johnson (1978) and Delipalla (1995) who find that the specific tax leads to larger price increases than the proportional, tending to be over-shifted (Chaloupka et al., 2010). ${ }^{4}$

\footnotetext{
${ }^{4}$ All three studies were tested for cigarette prices: Barzel and Johnson use a panel of US states for 1954-1972, whereas Delipalla uses a quarterly panel of EU countries for 1982-1990 (Chaloupka et al., 2010).
} 
In general, higher prices resulting from increased tax (irrespective of the component) lead to reduction in consumption (Chaloupka and Warner, 2000; Chaloupka et al., 2000; Ross and Chaloupka, 2006). Therefore, the excessive increase in cigarette excises can in turn negatively affect the government budget. ${ }^{5}$ However, the structure of the excise can also play an important role. For example, increased proportional excise can negatively influence government revenues due to down trading caused by smokers switching to lower-taxed cheaper brands. Number of studies have dealt with optimal structure of the excise taxes with the objective of maximizing the tax revenue (see Bohanon and van Cott, 1984; 1991; Kay and Keen, 1987; 1991; Keen, 1998; Delipalla and Keen, 2006). There is, probably, an optimal mix of specific and proportional excises in terms of maximizing excise tax revenue and/or minimizing its variations (World Health Organization, 2010), but it certainly largely depends on market characteristics and is probably country-specific. For example, Keen (1998) suggests that the share of proportional in total excise should be equal to the price elasticity of demand for maximizing both the level and the certainty of tax revenue. However, there is still no consensus on the composition of the cigarette excises including concrete shares of different tax components in the total.

Nevertheless, it is obvious that both components have their advantages and disadvantages. In general, specific excises are associated with more predictable budget revenue, lower price differentials, easier administration and calculation, whereas proportional excises automatically adjust to inflation ${ }^{6}$, tax higher profit margin and protect domestic production (Ross, 2004; Keen, 1998; Delipalla and O'Donnell, 1998; and Cnossen, 1992). Delipalla and O'Donnell (1998) claim that countries that have significantly developed their own production and cultivation of tobacco often favor the proportional excise tax because of the multiplier effect, which increases the price advantage of usually cheaper domestic products in relation to more expensive products of multinational companies. In the same time, proportional taxes are less advantageous for profit (Delipalla and Keen, 1992) so multinational companies would be expected to lobby for specific-type-taxation (Delipalla and O’Donnell, 1998).

Different structures (and levels) of excises cause differences in cigarette prices among countries. Excessive tax burden on cigarettes can give rise to legal purchase of cigarettes at

\footnotetext{
${ }^{5}$ Bosnia and Herzegovina has recently faced serious problems in this respect. Within the framework of the EU accession (harmonisation) process, cigarette excises in Bosnia and Herzegovina have increased. However, an increase of cigarette excises did not result in an expected growth of revenues because of the reduction of legal consumption of cigarettes. The immediate consequence of increasing the cigarette excises was an expansion of the fine-cut tobacco market (less heavily taxed at that time) and a gradual migration of consumers from the legal to the illegal tobacco market, which intensified after an increase in excises on fine-cut tobacco. This was confirmed by the high import of paper for machine rolling of cigarettes, coupled with the significant reduction of the official domestic production of cigarettes, as well as by the rapidly expanding discrepancy between the taxable consumption of tobacco and the prevalence of smoking.

${ }^{6}$ Tax systems based on high proportional excise are usually implemented in inflationary environments to benefit from price increases voluntarily made by producers.
} 
lower prices in neighboring countries (having a relatively lower tax burden) but also to contraband and other illegal activities. Illicit trade of tobacco products is a significant problem for governments around the world. The major motives for illicit trade are high tax levels, which provide strong incentives for smugglers to benefit from tax avoidance. See Delipalla (2009a) and (2009b) for these aspects of tobacco taxation. Illicit trade of tobacco products not only results in a significant loss in tax revenues, but also affects public order. The money generated in the "black market" through informal activities can be used for financing organized crime and other illegal activities.

Irrespective of various characteristics (effects) of specific and proportional excises, when making judgements of appropriate structure of the excise taxes, we should go back to the essence and fundamental principles of excise taxation. Besides significant (direct and indirect) fiscal effects, excise taxes have been introduced worldwide predominantly for social, healthrelated, ecological and other similar reasons. Moreover, selective sales taxes (excises) are generally introduced to treat externalities related to the consumption of specific goods. To this end, the basic rationale for cigarettes taxation lays is compensating the society for external costs of smoking. Since most externalities are associated with a particular characteristic of the good in question, the best instrument for correcting the behavior deemed inappropriate (i.e. consumption of cigarettes) is likely to be a specific tax on that characteristic (Keen, 1998). Moreover, Cnossen (1992) argues that specific taxation is a better instrument to internalize the "external costs" of smoking, since it hits the cause of the costs directly and does not tax items that do not contribute to the costs (such as wrappers), or even mitigate the effects of smoking (such as filters). Pirttilä (1997) also shows that wholly specific taxation is optimal once the externality is large enough to have any effect on policy.

\section{Cigarette taxation in the EU}

The structure and level of cigarette taxes are important determinants of prices, tax revenues and consumer behavior. Hence, these aspects should be taken into account while (re)forming the cigarette tax regime. Tobacco products within the EU are heavily taxed. Aiming to harmonize the systems of indirect taxation of its members, the EU implemented several Directives on excise taxes. The first Directive on tobacco taxation from 1972 has set the structure of taxation for tobacco products requiring a combination of specific and proportional (Directive 72/464/EEC). It also mandated minimum targets for cigarette taxes (both as absolute level and as a percentage of retail price), and provided a range for the specific/proportional tax ratio in the total tax structure. The first tobacco directive was clearly favoring the proportional component since a majority of EC members at that time had an entirely proportional tax structure. After a while, when countries with predominantly specific 
taxation joined the Community (Denmark, Ireland and the UK), a second tobacco directive was approved in 1977 (Directive 77/805/EEC) increasing the proposed share of the specific excise putting the proposed ratio not in relation to total excise but to total tax burden including the VAT. For a nice overview of how the proposed structure (in terms of upper and lower limits for specific and proportional components) has changed over time and potential reasons behind those changes see (Delipalla, and O'Donnell, 1998).

The currently in effect EU Directive 2011/64/EU also prescribes boundaries according to which from January 1, 2014 the specific excise tax on cigarettes should be neither less than $7.5 \%$ nor more than $76.5 \%$ of the total tax burden, which includes the specific and the proportional excise tax and the VAT imposed on the weighted average retail selling price. It is also stipulated that the total excise tax should not be less than EUR 90 per 1,000 cigarettes, or $60 \%$ of the weighted average retail price.

The share of total tax burden (including VAT) in the weighted average retail selling price of cigarettes in EU countries ranged in 2015 from the lowest $69.5 \%$ in Latvia, to the highest $85.7 \%$ in the UK.

Figure 1: The tax burden on cigarettes in EU countries in 2015 (in \% of the weighted average price-WAP)

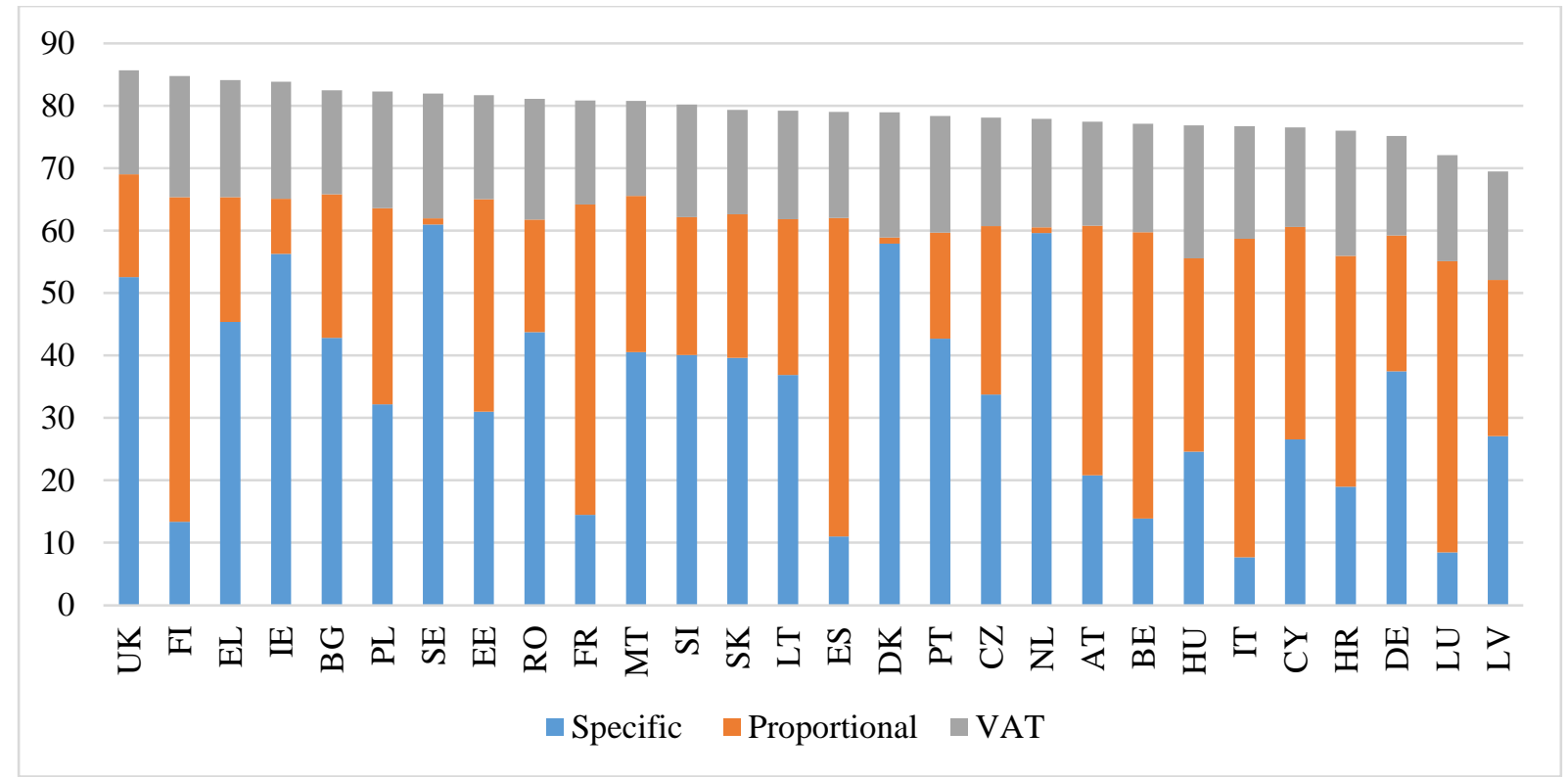

Sources: European Commission, 2015; own calculations.

Although the minimum excise tax and the desirable range for the specific excise rate are prescribed with the Directive, Member States independently determine the shares of specific or proportional tax component in the overall excise tax structure, as long as they are within the allowable range. In general, EU countries do not have the unique position on the desirable 
structure of the excise taxes (figure 2). Therefore, the share of the specific excise tax in the total ranges between $13.1 \%$ in Italy and $98.4 \%$ in Netherlands. Specific excises are strongly preferred by northern EU countries - Denmark, Sweden and Netherlands (having almost the full specific excise), whereas Italy, Luxembourg and Spain predominantly rely on the proportional excise. On average, the share of specific in total cigarette excises in the EU amounts to $54.3 \%$, whereas $45.7 \%$ refers to the proportional component.

Figure 2: The structure of the excise taxes on cigarettes in EU countries in 2015

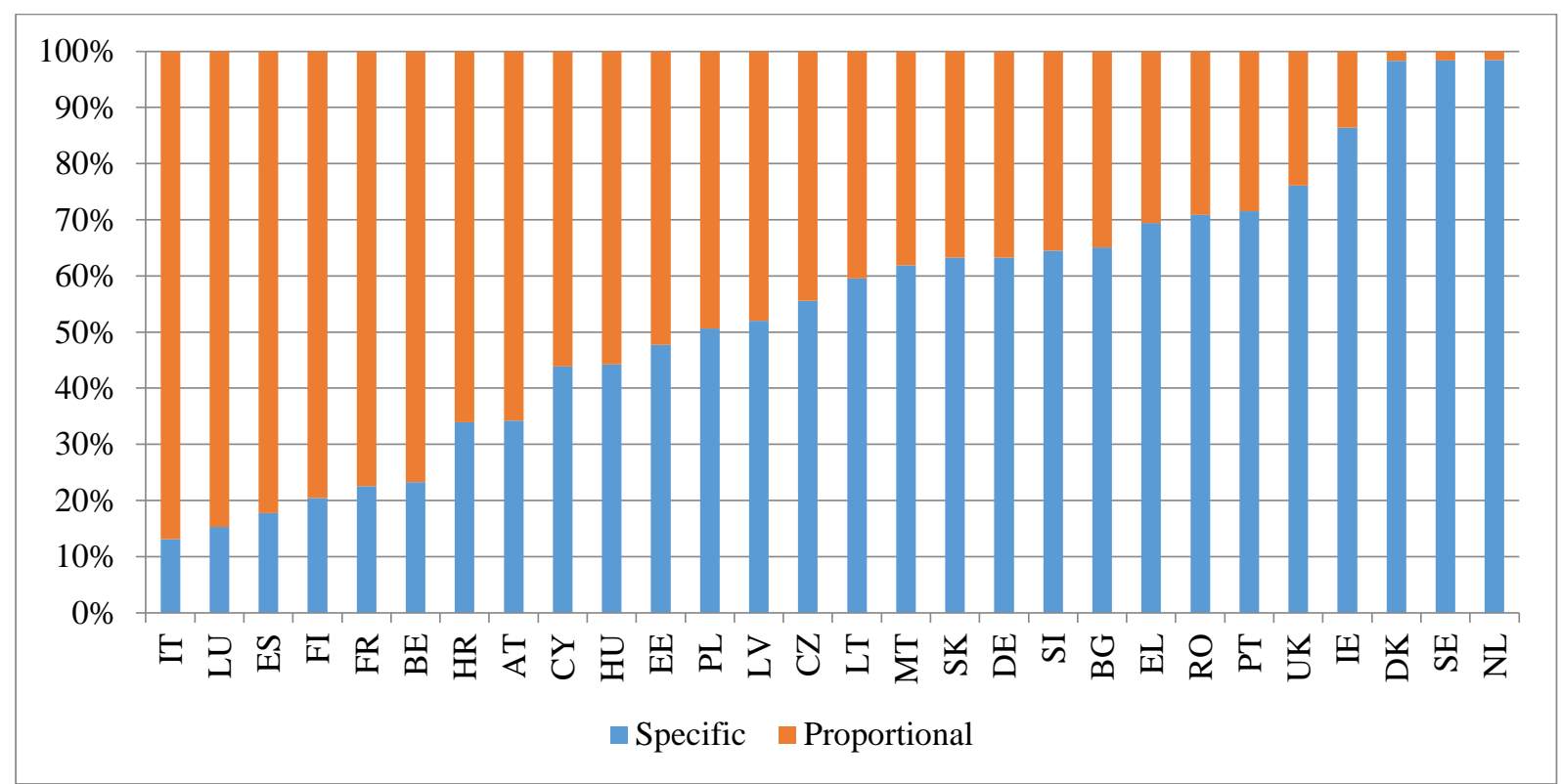

Sources: European Commission, 2015; own calculations.

The differences in the excise structure among countries have a strong indirect effect on tax revenue (through prices and consumption). Intuitively, the lower price of cigarettes should be associated with lower excise revenue. However, this might not be the case if the structure of the cigarette excise or level of prices itself causes (or is paired with due to exogenous reasons) decreasing consumption.

Average weighted average price per 1,000 cigarettes in EU countries has been increasing from 157 EUR in 2008 to 221 EUR in 2015. In the same time the consumption of cigarettes has decreased significantly - from 1,422 cigarettes per capita to 969 cigarettes per capita (a decrease of almost 1/3). In terms of per capita revenue - the effect of a decrease of consumption seems to be compensated by increasing prices, which made per capita revenue stable throughout the period at about 145 EUR per capita. This is exactly what EU policies have aimed at - decreasing consumption without significantly harming the revenue side of the national government budgets. 
Figure 3: Weighted average price of cigarettes and consumption in EU countries in 2015

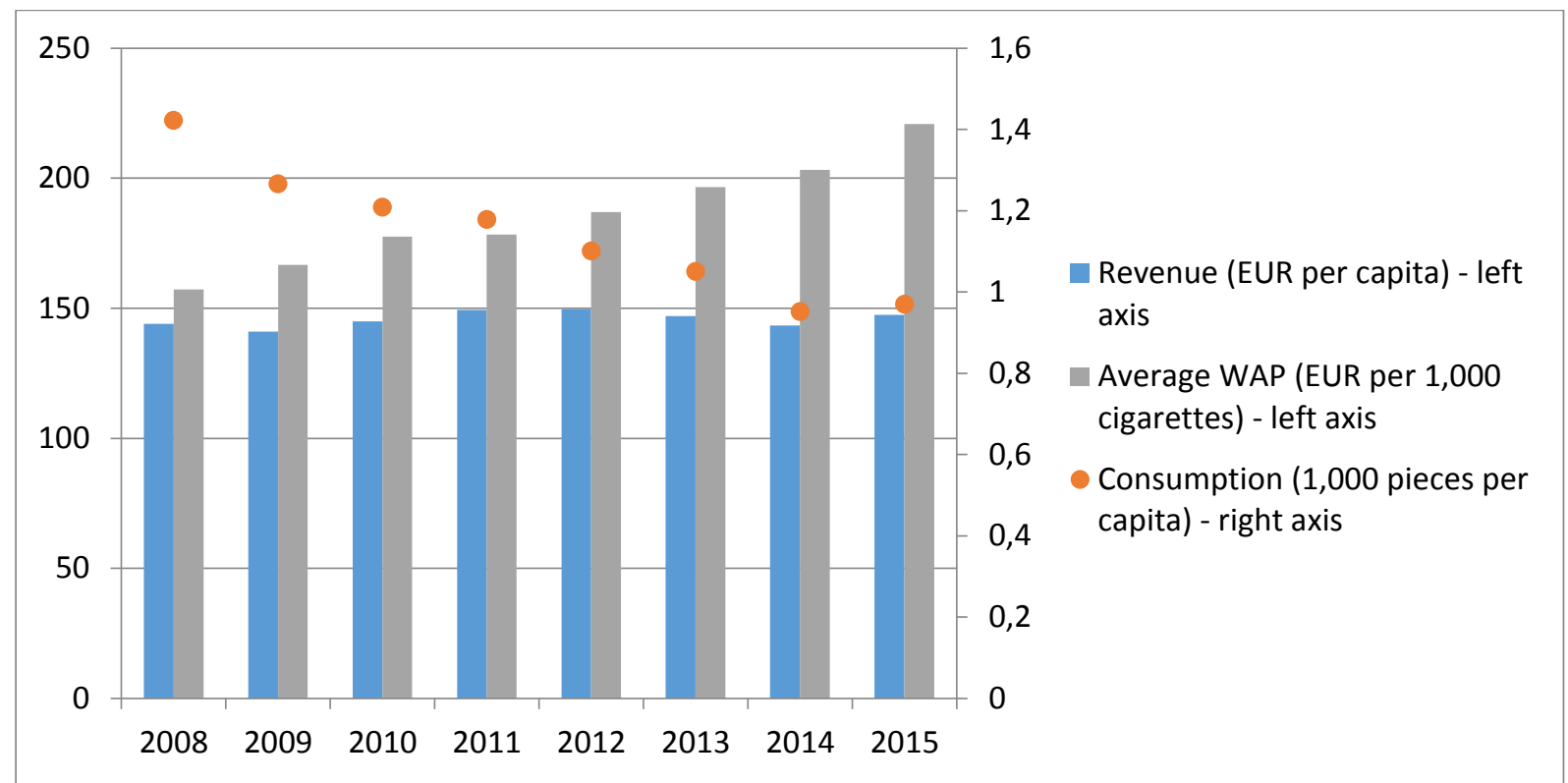

Sources: European Commission, 2015; own calculations.

An overview of the significance of revenues from excise taxes on cigarettes in the overall budget revenues and GDP (figure 4) in EU countries reveals that cigarette excises are not equally significant in all countries. The share of total cigarette excise revenue in Bulgaria is the highest of all EU member states amounting to slightly less than $6 \%$ of total general government revenue and more than $2.3 \%$ of GDP. In general, excise taxes on cigarettes are relatively more important source of budgetary revenue in new than in old EU member states.

Figure 4: Cigarette excise tax revenue in EU countries in 2015 (in \%)

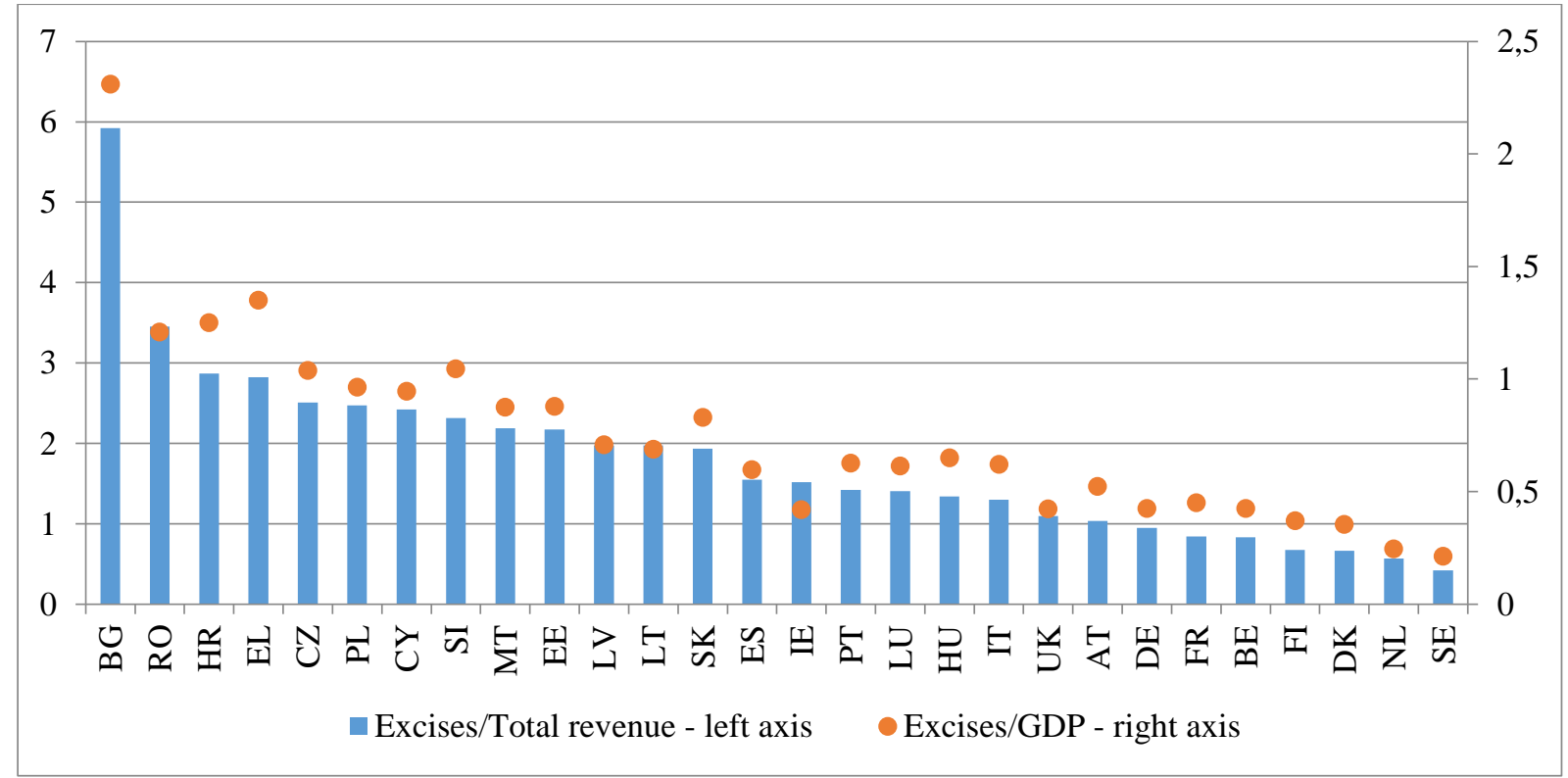

Sources: European Commission, 2015 and Eurostat; own calculations. 
Given that the total cost of smoking in the EU is estimated to about $4.6 \%$ of EU's combined GDP (GHK, 2012) and having in mind that the tobacco tax revenue should be compensating the society for external costs of smoking, cigarette excises should still be increased (if evaluated on theoretical grounds only). On the other hand, tobacco excise tax revenues should not exceed the external costs of smoking, unless the marginal cost of raising an additional euro of excise tax revenue is lower than the marginal cost of raising other taxes, e.g. VAT.

\section{Recent trends in cigarette taxation}

EU member states have increasingly approached the upper limit for the share of specific excise tax in the total tax burden. This is confirmed by historical data on a decrease of the proportional and an increase of the specific excise tax in EU Member States from 2008 to 2015 (figures 5 and 6). During this period, only four countries - Finland, Hungary, Estonia and Lithuania - have increased the proportional excise tax and other (23 out of 27$)^{7}$ countries have significantly decreased this component of the excise tax. The reduction of the proportional excise in some countries was so high that they almost switched to full-specific system (e.g. Sweden decreased the rate by $38.2 \%$ of WAP).

Figure 5: A decrease of the proportional (ad valorem) excise tax in EU countries from 2008 to 2015 (in \% of WAP)

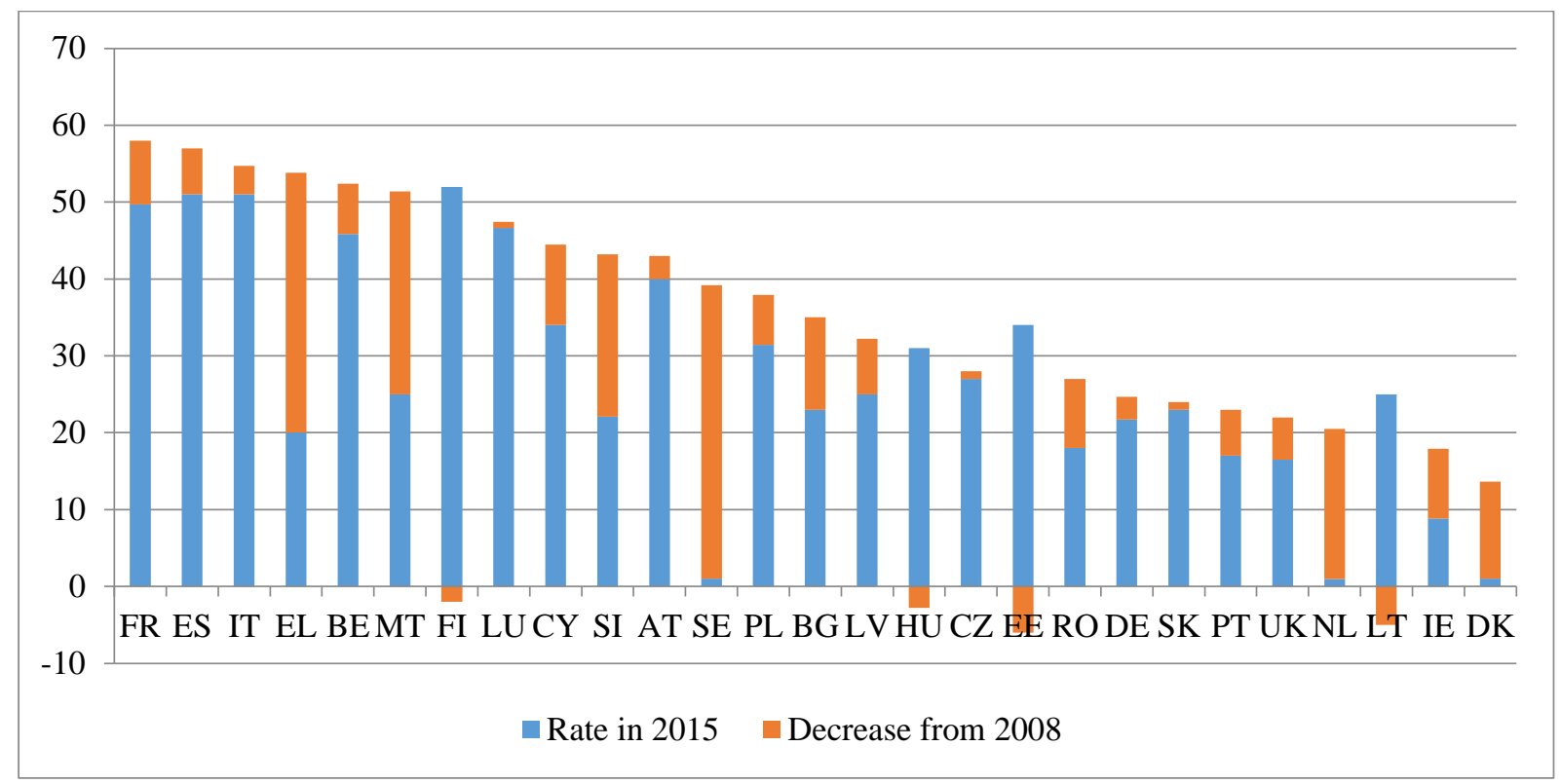

Sources: European Commission, 2008 and 2015; own calculations.

\footnotetext{
${ }^{7}$ Croatia is excluded here because it became a member state only in 2013.
} 
Countries that have reduced the proportional excise tax have at the same time increased the specific (figure 6). This trend has its practical but also theoretical footing. Among other effects already explained in previous chapters, by decreasing the proportional excise tax, the sensitivity of the tax system to changes in prices and consumer preferences reduces. The restructuring of the excise tax provides for the system to be less dependent on manufacturers' pricing policy and consumers' preferences and down trading.

Figure 6: An increase of the specific excise tax in EU countries from 2008 to 2015 (in \% of WAP)

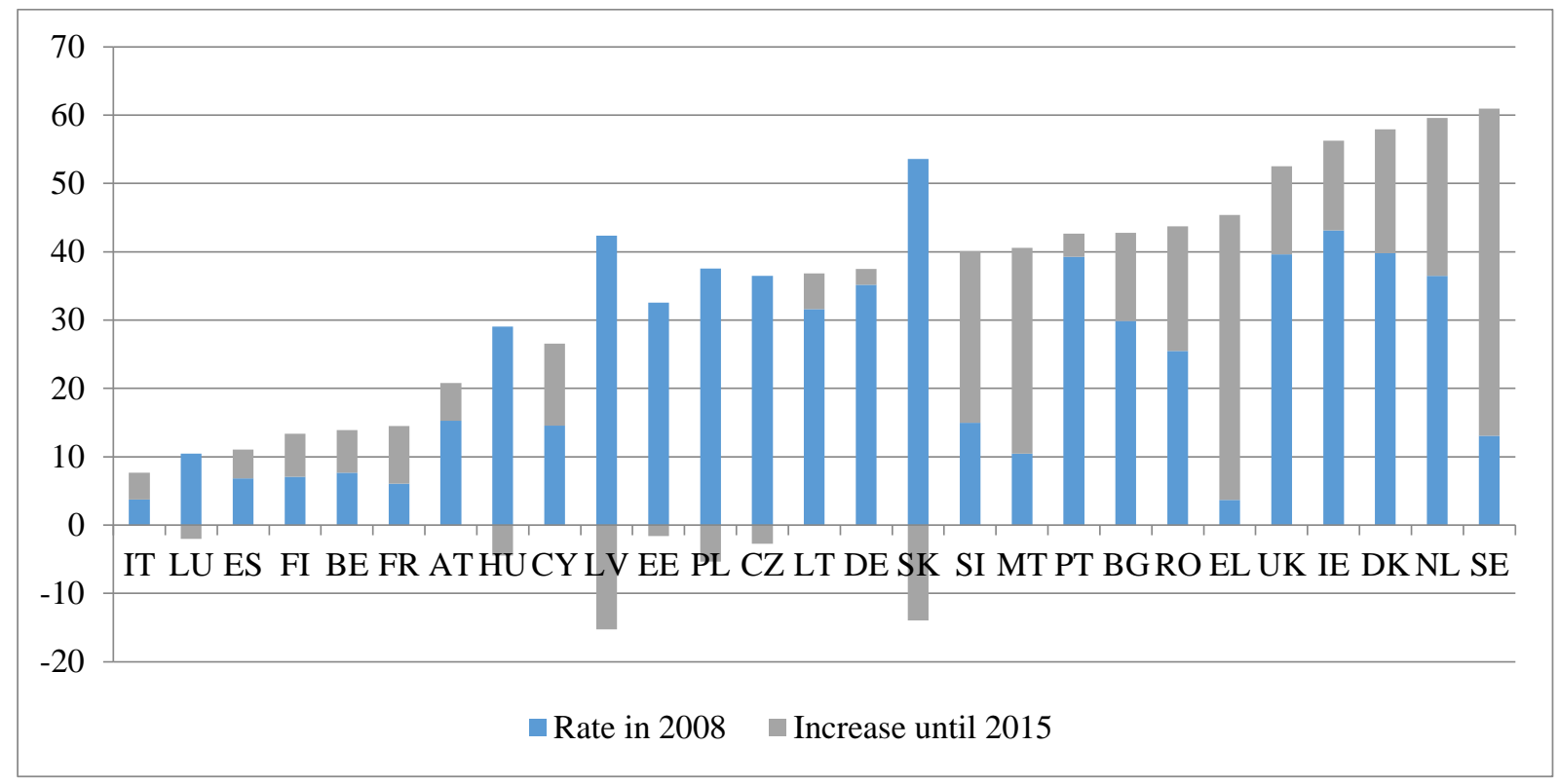

Sources: European Commission, 2008 and 2015; own calculations.

Due to already high tobacco taxes, EU countries are focusing on the structural improvements to grow revenues (and decrease consumption) as the scope for large tax increases has diminished. However, the extent to which those structural adjustments have really been effective in increasing the tax revenue is unknown. This and several other questions will be dealt with through the empirical analysis conducted in the next chapter.

\section{The influence of the excise structure on consumption and government revenue}

The goal of the empirical analysis is to test the hypothesis of the influence of the structure of cigarette excises on consumption and excise tax revenue, as well as to determine the impact of the existence of domestic tobacco production on the share of proportional component in the total excise tax. There have been several attempts to perform empirical analysis of potential effects of the structure of cigarette excises on consumption and government revenue in the European Union (see for example Chaloupka et al., 2010). However, many findings proved to be statistically insignificant, probably due to reasons already pointed out in Keen (1998). Our 
analysis is based on European Commission annual data on the cigarette excise structure, number of cigarettes released for consumption, weighted average prices and cigarette excise revenue for EU countries in the period from 2008 to 2015. Other independent variables related to GDP, population and tobacco production are adopted from Eurostat. The summary statistics of the final sample used for the investigation are reported in Table 1.

Table 1: Summary statistics

\begin{tabular}{|c|c|c|}
\hline Variables & Mean & St. Dev. \\
\hline Real excise tax revenue (in million EUR) $^{\mathrm{a}}$ & $2,799.89$ & $3,768.80$ \\
\hline Specific excise tax (in $\%$ of WAP ${ }^{b}$ ) & 29.3572 & 16.12924 \\
\hline Proportional excise tax (in \% of WAP) & 32.55872 & 14.94535 \\
\hline Cigarette consumption (in 1,000 pieces) & $20,459,307$ & $24,633,097$ \\
\hline Cigarette consumption per capita (in 1,000 pieces) & 1.518123 & 1.261764 \\
\hline Real WAP (in EUR per 1,000 cigarettes) $^{\mathrm{a}}$ & 199.872 & 84.59771 \\
\hline Real GDP per capita (in million EUR) ${ }^{a}$ & 0.02624117 & 0.01718265 \\
\hline Country population $^{\mathrm{c}}$ & $18,004,890$ & $22,822,788$ \\
\hline \multicolumn{3}{|l|}{ a) Deflated using HICP $(2015=100)$ - annual data } \\
\hline \multicolumn{3}{|c|}{ b) WAP - Weighted Average Price per 1000 cigarettes pursuant to Art. 8(2) Dir. 2011/64/EU } \\
\hline \multicolumn{3}{|c|}{ c) Models for revenue and consumption are estimated using country population as analytical weights. } \\
\hline \multicolumn{3}{|c|}{ Note: Data for Croatia were only completely available from 2014 and data on government revenue for } \\
\hline \multicolumn{3}{|c|}{ Romania is not available for 2013 so our estimates are based on a total of 217 observations. } \\
\hline
\end{tabular}

Sources: European Commission, Eurostat; own calculations.

To investigate the impacts of specific ( $\left.\boldsymbol{s p} \boldsymbol{c}_{\boldsymbol{j} \boldsymbol{t}}\right)$ and proportional (advalorem) tax rates $\left(\boldsymbol{a d} \boldsymbol{v}_{\boldsymbol{j} \boldsymbol{t}}\right)$ on cigarette consumption per capita $\left(\boldsymbol{c o n s c a p}_{j t}\right)$ we use the following empirical model:

$$
\operatorname{conscap}_{j t}=\alpha_{j}+\delta_{t}+\operatorname{spc}_{j t} \beta_{1}+a d v_{j t} \beta_{2}+\operatorname{price}_{j t} \beta_{3}+\operatorname{realgdpcap}_{j t} \gamma+v_{j t}
$$

The cigarette consumption per capita depends on country fixed effects $\left(\boldsymbol{\alpha}_{\boldsymbol{j}}\right)$, year fixed effects $\left(\boldsymbol{\delta}_{\boldsymbol{t}}\right)$, specific excise tax rates $\left(\boldsymbol{s} \boldsymbol{p} \boldsymbol{c}_{\boldsymbol{j} \boldsymbol{t}}\right)$, proportional tax rates tax rates $\left(\boldsymbol{a d} \boldsymbol{v}_{\boldsymbol{j} t}\right)$, real cigarette prices $\left(\boldsymbol{p r i c e}_{\boldsymbol{j} \boldsymbol{t}}\right.$ ) and real GDP per capita. We control for real GDP per capita as time-varying country-specific economic characteristic because countries in our samples can differ substantially in this characteristic having a significant impact on variables of interest. Country and year fixed effects are included to control for differences in variables of interest across these countries and time-varying factors that may affect variables of interest.

Table 2 presents estimates of the effect of the tax structure on the consumption of cigarettes per capita. 
Table 2: Cigarette consumption per capita measured in 1,000 pieces

\begin{tabular}{lrr}
\hline Coefficient & Value & St. error \\
\hline Specific excise tax & $*-0.0113732$ & 0.0058515 \\
Proportional excise tax & -0.0087681 & 0.0075362 \\
Real cigarette price & $* * *-0.0038080$ & 0.0008035 \\
R squared & & 0.8726 \\
\hline Notes: $* * *$ p-value $<0.01, * * 0.01<$ p-value $<0.05, * 0.05<$ p-value $<0.10$. & \\
\hline
\end{tabular}

Sources: own calculations.

The results of the empirical analysis suggest that the cigarette consumption per capita would decline by more than 11 pieces, if the specific excise tax rose by 1 percentage point of WAP. While the specific excise tax is significant at $10 \%$ level considering that the corresponding $\mathrm{p}$ value equals to 0.0535 , the proportional excise tax is not significant at usual significance levels. Also, if real cigarette price per 1,000 cigarettes rose by 1 EUR, the cigarette consumption per capita would decline by almost 4 pieces.

We also explore the effects of the tax structure on real government revenue from excise taxes measured. The empirical model is presented by the following equation:

$$
\begin{aligned}
\operatorname{realrev}_{j t}= & \alpha_{j}+\delta_{t}+\operatorname{spc}_{j t} \beta_{1}+a d v_{j t} \beta_{2}+\operatorname{cons}_{j t} \beta_{3}+\operatorname{price}_{j t} \beta_{4}+\operatorname{realgdpcap}_{j t} \gamma \\
& +v_{j t}
\end{aligned}
$$

The real excise tax revenue in country $j$ year $t(\boldsymbol{r} \boldsymbol{e a l r e v} \boldsymbol{j t})$ depends on country fixed effects $\left(\boldsymbol{\alpha}_{j}\right)$, year fixed effects $\left(\boldsymbol{\delta}_{\boldsymbol{t}}\right)$, specific excise tax rates $\left(\boldsymbol{s} \boldsymbol{p} \boldsymbol{c}_{\boldsymbol{j} t}\right)$, proportional tax rates $\left(\boldsymbol{a d} \boldsymbol{v}_{\boldsymbol{j} t}\right)$, cigarette consumption measured in 1,000 pieces $\left(\boldsymbol{c o n s}_{\boldsymbol{j} \boldsymbol{t}}\right)$, real cigarette prices $\left(\boldsymbol{p r i c e} \boldsymbol{e}_{\boldsymbol{j}}\right)$ and real GDP per capita as time-varying country-specific economic characteristic $\left(\right.$ realgdpcap $\left.{ }_{j t}\right)$.

Table 3: Real Government Revenues from Cigarette Tax

\begin{tabular}{lrr}
\hline Coefficient & Value & St. error \\
\hline Specific excise tax & $* * 21.72$ & 10.17 \\
Proportional excise tax & 14.21 & 13.13 \\
Cigarette consumption & $* * * 0.00001282$ & 0.000004139 \\
Real cigarette price & $* * * 4.278$ & 1.516 \\
$\mathrm{R}$ squared & & 0.9956 \\
\hline Notes: $* * *$ p-value $<0.01, * * 0.01<\mathrm{p}$-value $<0.05, * 0.05<\mathrm{p}$-value $<0.10$. & \\
\hline \hline Sources: own calculations.
\end{tabular}


Table 3 presents the estimates on how changes in the specific and proportional excise taxes affect government revenues from the cigarette excise. The results reveal that the real government revenues from cigarette tax would increase by 21.7 million EUR $(0.776 \%)$, if the specific excise tax rose by 1 percentage point of WAP. While the specific excise tax is significant at $5 \%$ level, the proportional excise tax is not significant at all usual levels. Also, if real cigarette price rose by 1 EUR (per 1,000 pieces), the real government revenues from cigarette tax would increase by 4.3 million EUR (0.153\%). Finally, if cigarette consumption rose by 1,000 pieces, the real government revenues from cigarette tax would increase by 12.82 EUR.

Although specific excise proved to be more efficient in reaching governments' objectives, many EU countries still predominantly rely on the proportional excise. To explore the impact of the existence of domestic tobacco production on the share of the proportional in the total excise tax, we specify the model using the following equation:

$$
\operatorname{advp}=\alpha+\operatorname{dprod} \cdot \beta
$$

The share of proportional in total excise tax $(\boldsymbol{a d} \boldsymbol{v p})$ is calculated as proportional over total excise tax and represents the relative importance of proportional in total excise tax. In the model, it depends on the binary independent variable indicating the existence of a developed domestic tobacco production (dprod, equals 1 if the country has tobacco production, and 0 otherwise). Countries that were (according to the Eurostat's data on tobacco production) classified as having a developed domestic tobacco production are: Bulgaria, Greece, Spain, France, Croatia, Hungary, Italy, Poland and Romania.

The coefficient of tobacco production (binary variable) is estimated at 0.13745 , indicating that other things being equal, countries with significant tobacco production have 0.13745 percentage points higher share of the proportional in total excise tax than those without domestic production. The standard error being 0.03662 , indicates that the tobacco production variable is significant at the alpha level of 0.01 .

\section{Concluding remarks}

The structure of excise taxes on cigarettes greatly affects the price of cigarettes, the level and the structure of consumption, but also the amount of tax revenue. EU Directives prescribe the combination of the specific and the proportional (ad valorem) excise tax on cigarettes. However, Member States more or less independently determine the shares of one or another component in the overall excise tax structure. Therefore, the share of total tax burden 
(including VAT) in the weighted average retail selling price of cigarettes in EU countries varies from $69.5 \%$ to $85.7 \%$ in 2015 . The share of the specific excise tax in the total ranges between $13.1 \%$ and $98.4 \%$. Specific excises are strongly preferred by northern EU countries Denmark, Sweden and Netherlands, whereas Italy, Luxembourg and Spain predominantly rely on the proportional excise.

EU member states are continuously approaching the upper limit for the share of specific excise tax in the total tax burden. The results of the empirical analysis suggest that this is a right direction to take because an increase in the specific component of the excise tax has a positive impact on the tax revenue and negatively influences the consumption. The proportional tax component proved to be statistically insignificant in this respect. Although it is evident that specific excises are more effective in conducting government policies, some countries still predominantly rely on this component. Econometric analysis has confirmed that one of the possible reasons for this might be the developed domestic tobacco production. Countries with domestic production might use proportional excises to increase the absolute price difference between cheaper domestic and often more expensive multinational brands.

EU countries should rely more on specific excise element by increasing the specific excise as percentage of total cigarette tax inclusive of VAT. This should also be stipulated by further changes in cigarette directives. The structural strengthening of the excise tax (decreasing the share of proportional component) would lower the risks of declining revenues as a result of down trading to cheaper products and provide for better fiscal predictability. High proportional tax creates a huge price and tax yield differences (between low-priced and premium-priced cigarettes) and encourages the supply of cheap cigarettes with lower tax incidence. 


\section{References}

Anderson, S. P., de Palma, A. and Kreider, B., 1997, Tax incidence and efficiency in differentiated product oligopoly. Mimeo, University of Virginia.

Antoñanzas, F., Rodríguez, R., 2007, Tobacco Policies in the European Union: Need for State and Continental Harmonisation? European Journal of Health Economics 8(4): 301-4.

Barzel, Y., 1976, An alternative approach to the analysis of taxation. Journal of Political Economy, vol. 84, pp. 1177-97.

Bohanon, C. E., van Cott, T. N., 1991, Product quality and taxation: A reconciliation. Public Finance Quarterly 19:233-7.

Bohanon, C. E., van Cott, T. N., 1984, Specific taxes, product quality and rate-revenue analysis. Public Finance Quarterly, 12:500-11.

Chaloupka, F. J., et al., 2000, Taxation of tobacco products. In: Jha P., Chaloupka F. J., eds., Tobacco control in developing countries. Oxford, Oxford University Press.

Chaloupka, F. J., Warner, K. E., 2000, The economics of smoking. In: Culyer, A. J., Newhouse, J. P., eds. Handbook of Health Economics, Vol 1. Amsterdam, Elsevier, $1539-1627$

Chaloupka, F. J., Peck, R., Tauras, J. A., Xu, X., Yurekli, A. 2010, Cigarette Excise Taxation: The Impact of Tax Structure on Prices, Revenues and Cigarette Smoking.

Cnossen S., 2001, How Should Tobacco Be Taxed In EU-Accession Countries? CESifo Working Paper No. 539.

Cnossen, S., 1992, Intrigues around the tobacco excise in the European Community, International Tax Review, 2, 127-137.

Cournot, A., 1960, originally published 1838, Researches into the Mathematical Principles of the Theory of Wealth, London: Frank Cass \& Co.

Cremer, H., Thisse, J.-F., 1994, Commodity taxation in a differentiated oligopoly. International Economic Review, vol. 35, pp. 613-33.

Delipalla, S., 2009a, Commodity tax structure and informal activity, Bulletin of Economic Research, 61(3):283-294.

Delipalla, S., 2009b, Tobacco tax structure and smuggling. FinanzArchiv: Public Finance Analysis, 65(1):93-104.

Delipalla, S., 1995, Specific versus ad valorem taxation: empirical evidence from the European cigarette industry. Mimeo, University of Kent.

Delipalla S., Keen, M. J., 2006, Product quality and the optimal structure of commodity taxes. Journal of Public Economic Theory, 8(4):547-554.

Delipalla, S., Keen, M. J., 1992, The comparison between ad valorem and specific taxation under imperfect competition. Journal of Public Economics, 49:351-367.

Delipalla, S., O’Donnell, O., 2001, Estimating tax incidence, market power and market conduct: The European cigarette industry. International Journal of Industrial Organisation, 19:885-908. 
Delipalla, S., and O'Donnell, O., 1998, The Comparison between Ad Valorem and Specific Taxation under Imperfect Competition: Evidence from the European Cigarette Industry. Dixit, A. K., Stiglitz, J. E., 1977, Monopolistic competition and optimum product diversity. American Economic Review, vol. 67, pp. 297-308.

Ekpu, V. U., \& Brown, A. K. 2015, The Economic Impact of Smoking and of Reducing Smoking Prevalence: Review of Evidence. Tobacco Use Insights, 8, 1-35.

European Commission, 2015, Excise Tax Tables: Part III - Manufactured Tobacco for 2015. European Commission, 2007, Excise Tax Tables: Part III - Manufactured Tobacco for 2007. GHK, 2012, A study on liability and the health costs of smoking. DG SANCO (2008/C6/046).

Johnson, T. R., 1978, Additional evidence on the effects of alternative taxes on cigarette prices. Journal of Political Economy, vol. 86, pp. 325-8.

Kay, J. A., Keen M. J., 1991, Product quality under specific and ad valorem taxation. Public Finance Quarterly, 19:238-47.

Kay, J. A., Keen, M. J., 1987, Commodity taxation for maximum revenue. Public Finance Quarterly, 15:371-85.

Kay, J. A., Keen, M. J., 1983, How should commodities be taxed? European Economic Review, 23:339-358.

Kay, J. A., Keen, M. J., 1982, The structure of tobacco taxes in the European Community. IFS Report Series No.1, Institute for Fiscal Studies.

Keen, M., 1998, The Balance between Specific and Ad Valorem Taxation. Fiscal Studies, vol. 19, no. 1, pp. 1-37.

Lightwood J, Collins D, Lapsley H, et al., 2000, Estimating the costs of tobacco use. In: Jha P., Chaloupka F. J., eds. Tobacco Control in Developing Countries, Oxford: Oxford University Press, 2000.

Mathers, C. D., Loncar, D., 2006, Projections of global mortality and burden of disease from 2002 to 2030. PLoS Medicine, 3(11):e442.

Myles, G., 1996, Imperfect competition and the optimal combination of ad valorem and specific taxation. International Tax and Public Finance, 3:29-44

Pirttilä, J., 1997, Aspects of environmental taxation under imperfect competition. Mimeo, University of Essex.

Ross, H., 2004, The Economics of Tobacco and Tobacco Control in the European Union. In Tobacco or Health in the European Union: past, present and future“. European Commission, Directorate-General for Health and Consumer Protection, 69-98.

Ross, H., Chaloupka, F. J., 2006, Economic policies for tobacco control in developing countries. Salud Publica Mex. 2006;48 Suppl 1:S113-20

Skeath, S. E., Trandel, G. A., 1994, A Pareto comparison of ad valorem and unit taxes in noncompetitive environments. Journal of Public Economics, 53:53-71

Stern, N. H., 1987, The effects of taxation, price control and government contracts in oligopoly and monopolistic competition. Journal of Public Economics, vol. 32, pp. 13358. 
Suits, D. B., Musgrave, R. A., 1955, Ad valorem and unit taxes compared. Quarterly Journal of Economics, vol. 67, pp. 598-604.

Warner, K. E., Hodgson, T. A., Carroll, C. E., 1999, Medical costs of smoking in the United States: Estimates, their validity, and their implications. Tobacco Control, 8(3):290-300.

Wicksell, K., 1959, originally published 1896, Taxation in the monopoly case. In R. A.

Musgrave and C. S. Shoup (eds), Readings in the Economics of Taxation, London: Allen \& Unwin.

World Bank, 1999, Curbing the Epidemic: Governments and the Economics of Tobacco Control. New York: World Bank.

World Health Organization, 2011, Economics of tobacco toolkit: assessment of the economic costs of smoking.

World Health Organization, 2010, Technical Manual on Tobacco Tax Administration. World Health Organization, Geneva. 